\title{
Public and Private Saving and Investment ${ }^{1}$
}

\author{
Eric van Wincoop \\ Department of Economics,Boston University,270 Bay State Rd., Boston, MA 02215 \\ and \\ Jane Marrinan \\ Department of Economics, Universitat Pompeu Fabra,132 Balmes, 08008 Barcelona
}

June 3, 1996

\footnotetext{
${ }^{1}$ Work on the main body of this paper was initiated while the authors were research fellows at the Innocenzo Gasparini Institute for Economic Research in Milan, and continued while the first author was a visitor at the Institute for International Economic Studies in Stockholm. The first author acknowledges support from the European Community under the Human Capital Mobility Program. We would also like to thank Torsten Persson, Maurice Obstfeld, Fabio Canova, and seminar participants at IGIER, the Institute for International Economic Studies in Stockholm, the Summer Meetings of the Society for Economic Dynamics and Control in Nafplio, Greece, Birkbeck College, Northeastern University, the University of Venice, Tilburg University and the World Bank for many helpful comments and suggestions.
} 


\begin{abstract}
We decompose aggregate saving and investment into its public and private components and then document a variety of "stylized facts" associated with saving and investment rates for a sample of 15 countries over the period 1975-1989. In order to see whether these empirical relationships are consistent with a world of perfect capital mobility we develop a multi-country model with free trade in a riskfree bond and calibrate it to the fifteen OECD countries. We pay special attential to modeling the fiscal policy rules. The model performs remarkably well in accounting for a wide variety of time series relationships. Nonetheless the model is not able to capture the cross sectional aspect of the data. In particular, the model cannot account for both the large cross country correlation between aggregate saving and investment rates and the very negative cross country relationship between the public and private saving minus investment gaps.
\end{abstract}




\section{Introduction}

There is significant empirical evidence of a high positive correlation between aggregate saving and investment rates in both time series and cross country data for a broad range of countries. Although originally interpreted as reflecting a low degree of international capital mobility, the literature that developed since these Feldstein-Horioka findings has shown that the comovements between savings and investment can well be consistent with models of perfect capital mobility, for example, as a result of temporary but highly persistent technology shocks. ${ }^{1}$ But these previous studies, by focusing on the behaviour of national aggregates, miss important aspects of the relationship between saving and investment.

In this paper we highlight these aspects by decomposing saving and investment into their public and private parts for a set of 15 OECD countries for the period 1975-1989, a period characterized by a relatively high degree of capital mobility. The disaggregation leads to various striking empirical observations. Some of these empirical regularities have been documented before by various authors, but so far there has been no rigorous attempt to account for these stylized facts within a unified analytical framework. In order to fill this vacuum and better understand these empirical relationships, we develop a multi-country general equilibrium model with perfect capital capital mobility, calibrated to the set of 15 countries.

A first "stylized fact" is that, unlike the large aggregate saving-investment correla-

\footnotetext{
${ }^{1}$ For an overview of this literature see Feldstein and Bacchetta (1991), Tesar (1991), Goldstein and Mussa(1993) and Obstfeld (1995). At a theoretical level Obstfeld (1986) first showed that temporary productivity shocks can generate a positive time series correlation between saving and investment. At a numerical level, in open economy real business cycle models in which only a bond is traded internationally, Mendoza (1991) and Cardia (1991) show that temporary technology shocks can generate saving investment correlations of a magnitude similar to what is observed in the data. Finn (1990), Baxter and Crucini (1993) and Backus, Kehoe and Kydland (1992) show that even in open economy real business cycle models with perfect risksharing it is possible to generate the observed time series correlations between saving and investment in the presence of technology shocks. Under perfect risksharing saving rises even in response to permanent technology shocks. As a result of the risksharing consumption does not rise as much as income in the country facing the shock.
} 
tion, the contemporaneous time-series correlation between private saving and investment is on average close to zero. This was also pointed out by Bayoumi (1990). Many models that account for the high observed correlation between total saving and investment do not allow for a government sector. These models then automatically imply a high correlation between private saving and investment as well, in sharp contrast to the evidence. It is therefore clear that the role of the government sector is central to understanding the relationship between saving and investment rates.

A second finding concerns the behaviour of the public and private savings minus investment gaps. We demonstrate that for most of the countries the private sector gap is almost a perfect mirror of the public sector gap. This negative relationship between the gaps has also been documented in Soderstrom (1987), Summers (1988), Feldstein and Bacchetta (1991), Bosworth (1993), Iwamoto and van Wincoop (1994) and Argimon and Roldan (1994). It implies that an increase in the budget deficit (drop in the government S-I gap) is primarily domestically financed through a combination of higher private saving or crowding out of investment. At least three possible explanations have been suggested in the literature. The first is Ricardian equivalence, which says that given a time profile for government consumption, the particular timing of tax collections is unimportant for private consumers' desired consumption profile. Any decrease in government saving resulting from a current cut in taxes would simply be offset by a similar increase in private saving because consumers recognize that a reduction in taxes today must be balanced by tax increases in the future. An alternative explanation that has been suggested by Summers (1988) is that the government targets the current account and therefore adjusts the budget deficit to offset the gap between private saving and investment. Finally, Bosworth (1993) argues that the negative relationship may be partly a result of the business cycle. He argues that in a boom private investment tends to be high in relation to private saving, while automatic stabilizers induce a countercyclical pattern in the budget balance.

As a third stylized fact, there is a strong positive correlation between the private gap and the current account, but the government gap is not significantly correlated with the current account. Soderstrom (1987) and Borenzstein (1989) also find that there is no 
significant association between the budget deficit and the current account. For a sample of 30 countries Borenzstein (1989) finds the correlation between the current account and the budget deficit is negative in about half of the countries, and positive in the other half.

The multi-country real business cycle model developed here to understand these, and various other, stylized facts assumes that there is perfect capital mobility across countries. This means that a riskfree bond is freely traded internationally. The business cycles of countries are linked through movements in the endogenous world interest rate on these bonds, as well as fiscal and production shocks that are correlated across countries.

The paper devotes significant attention to modeling the government sector. Rules for government taxation, consumption and investment are specified, estimated using country data, and fed into simulations of the model. ${ }^{2}$ The rules depend on lags of these variables, government debt, and the budget surplus. Government debt plays an important role in the rules, since, as shown by Buiter (1984), the government budget constraint is satisfied as long as the fiscal variables depend sufficiently on government debt. We include the budget surplus (the change in the debt) to enter the fiscal rules since political debates indicate that governments are very much concerned with this flow variable. We also experiment with adding the current account to determine whether governments respond endogenously to current account imbalances. ${ }^{3}$

The model is applied both to time series moments and cross country moments. The latter are based on a cross section of 1989 saving and investment rates. The literature aimed at understanding the relationship between aggregate saving and investment has focused primarily on the time series relationship. This is because the models have been

\footnotetext{
${ }^{2}$ Government investment is often ignored in modeling the government sector. But while government consumption relative to GDP is on average six times the size of government investment to GDP, it is only twice as volatile.

${ }^{3}$ In some recent papers, Baxter (1993) and Kollman (1993) also study at a numerical level the role of fiscal policy in open economy real business cycle models. The fiscal rules are less general in those papers and are not estimated. In Baxter (1993) the fiscal rules for the tax rate and government consumption are simple AR processes. The government budget constraint is satisfied through lump sum taxation that retires the debt.
} 
either small open economy models (e.g. Cardia (1991) and Mendoza (1991)) or two country general equilibrium models (e.g. Finn (1990), Backus, Kehoe and Kydland (1992) and Baxter and Crucini (1993)). Here we adopt the approach developed in van Wincoop (1995) to solve multi-country models, which allows us to also consider the cross sectional relationships.

The model performs remarkably well in accounting for a wide range of time series moments describing the relationship between saving and investment rates, including the ones discussed above. Nonetheless the model is not able to capture the cross sectional aspect of the data. In particular, the model cannot account for both the large cross country correlation between aggregate saving and investment rates and the very negative cross country relationship between the public and private S-I gaps.

The remainder of the paper is organized as follows. Section 2 documents the empirical facts. Section 3 describes the model. Section 4 discusses model calibration and estimation of the fiscal rules. Section 5 analyzes the results. A careful sensitivity analysis is done as well. The final section draws conclusions and suggests avenues for future work.

\section{Data and Empirical Observations}

\subsection{The Data}

Appendix A contains details on data construction and data sources. Here we will confine ourselves to a brief discussion of the main problems with data construction. The aggregate, public and private saving and investment series for fifteen OECD countries are taken from the UN National Accounts for a sample of annual data from 1975 to 1989. For a smaller set of eight countries we also consider a longer sample that starts in 1960 . The advantage of the shorter sample is that it covers a relatively recent period during which institutional restrictions and barriers to international capital flows were far less significant than during earlier periods.

As is well known from Sachs (1981), Obstfeld (1986) and Stockman and Svensson (1987), the national accounts definition of aggregate saving is not equal to true saving. 
Capital gains and losses associated with the net international investment position are not included in the national accounts definition. ${ }^{4}$ This includes changes in the price of stock, bonds and other securities, as well as capital gains and losses are associated with inflation and exchange rate fluctuations. Because of the difficulty in measuring true saving, Baxter and Crucini (1993) compare model and data moments for what they call "basic saving". It is defined as GDP minus government and private consumption, thus ignoring income associated with the return on the net international asset position.

Of course this problem also applies to private and government saving. The national accounts definition of government saving is total receipts, minus government consumption, minus subsidies and other current transfers, minus net property income payments. The latter is largely interest on the debt, which is not the true real return on government debt. Since the size of the government debt is generally much larger than the net international asset position, the mismeasurement problem is probably even more severe at this disaggregated level.

We will consider three measures of aggregate, government and private saving. The first corrects real government saving by subtracting an inflation component from nominal interest on government debt. This is done by adding to the national accounts definition of government saving a term equal to inflation times the public debt. ${ }^{5}$ Private saving is defined as the difference between total saving (national accounts) and the corrected measure of government saving. The second type of saving measure is the national accounts measure, without any further adjustments. The third type of saving measure is based on the "basic saving" definition in Baxter and Crucini (1993). Total saving is equal to GDP minus private and government consumption: $Y-C-G$. Government saving is equal to that in the national accounts, plus net property income payments. This is $T-G$, where $T$ is a measure of net taxes, equal to tax revenues, minus subsidies and

\footnotetext{
${ }^{4}$ Even the part of net investment income not associated with capital gains, the difference between GNP and GDP, is notoriously poorly measured.

${ }^{5}$ This still does not fully deal with the measurement problem issue since capital gains and losses associated with fluctuations in the price of long term government debt are not accounted for. Moreover some government debt is denominated in foreign currencies. See Missale (1991) for evidence on the term structure and currency denomination of government debt in OECD countries.
} 
other current transfers. Private saving is the difference between total and government saving: $Y-T-C$.

Aggregate, government and private investment are obtained directly from the national accounts. Both saving and investment data are divided by GDP to convert them into rates.

\subsection{Empirical Observations}

Table 1 shows various moments for all three measures of saving. They are average time series moments across all countries, based on unfiltered data. The first saving measure is adopted as the benchmark, for which the results are shown in the first column.

Four important stylized facts appear. First, while the average time series correlation between aggregate saving and investment is 0.54 , the average correlation between private saving and investment is only 0.07 . Second, the correlation between private and government sector saving minus investment gaps is -0.68 . This is also illustrated in Figure 1, which shows that these gaps closely mirror each other. The government budget deficit is equal to $-\left(S^{g}-I^{g}\right)$. An increase in the budget deficit (decrease in the government gap) tends to be primarily domestically financed, either by somehow generating a rise in private saving, or by crowding out private investment. A combination of these two appears relevant: $S^{g}-I^{g}$ is positively correlated with private investment and negatively with private saving. Soderstrom (1987) also finds that that the financing of an increase in the budget deficit "is fairly evenly divided between an increase in the private sector saving ratio and a decline in the private sector investment ratio".

A third stylized fact is that the average correlation between the budget deficit and the current account is close to zero, while there is a large correlation of 0.63 between the current account and the private gap. A final stylized fact, which applies to aggregate data, is that on average there is a negative correlation between the current account and investment (-0.47) and a positive correlation between the current account and saving (0.36). The strong negative relationship between the current account and investment was first documented by Sachs (1981).

We can see from Table 1 that these stylized facts are robust to the measurement 
of saving. The only noteworthy change is that when the "basic saving" measure is applied the correlation between government saving and investment drops from 0.27 to -0.29. As a result the difference between the aggregate saving-investment correlation and the private saving-investment correlation drops from 0.47 to 0.24 . The much larger correlation between government saving and investment in the benchmark is entirely a result of a very negative correlation between interest on government debt and government investment.

Table 2 shows some country specific moments based on the benchmark saving measure. The negative correlation between the gaps is an even more robust feature of the data than the well documented positive correlation between aggregate saving and investment. In the absence of international capital flows we know that $\operatorname{corr}(S, I)=1$ and $\operatorname{corr}\left(G a p^{g}, G a p^{p}\right)=-1$. But with capital flows there is not necessarily a close relationship between these correlations. Indeed, countries like the Netherlands and the UK, where the correlation between aggregate saving and investment is close to zero, have a correlation between the gaps of less than $-0.8 .{ }^{6}$ Figure 2 shows plots of aggregate saving and investment rates for all countries. If we compare this to the plots for the gaps in Figure 1 it immediately apparant that the negative relationship between the gaps is much stronger and more robust than the positive relationship between the aggregate saving and investment rates.

Table 2 also shows striking differences between the aggregate S-I correlation and the private S-I correlation. In Canada, Finland, France, Sweden and the US the aggregate S-I correlation is quite close to 1 , while the private S-I correlation is approximately zero or negative. From the fifth column of the table we see that for about half of the countries there is a positive correlation between the government gap and the current account, while the opposite is the case for the other half, as in Borenzstein (1989). With

\footnotetext{
${ }^{6}$ The only countries where the correlation between the gaps is close to zero are Germany and Norway. For these countries the correlation between aggregate saving and investment is close to zero as well (Germany) or even negative (Norway). The outlier in Norway is a result of temporary significant oil investments at the end of the seventies, financed by borrowing from abroad. In Germany both the government and private gaps show very little volatility. But they are still very negatively correlated at the high frequency, with a correlation of -0.68 for first differences.
} 
the exception of the US, the private gap is positively correlated with the current account in all countries.

Columns 2-4 in Table 3 report average time series moments when applying different filters to the data. The last column shows cross country correlations, based on a cross section of saving and investment rates for 1989. The second column considers first differenced data, which captures relatively high frequency fluctuations. The third column extracts a Hodrick-Prescott (100) filter, which leaves fluctuations at the business cycle frequency. The table shows that the results are not significantly affected by either of these filtering methods. In order to see to what extent the business cycle is responsible for the observed moments, in column 4 the business cycle is first filtered out of the data. This is done by regressing all variables on a constant and HP(100) filtered real GDP. The error terms, which are orthogonal to HP filtered output, are used to compute the moments. While this lowers the aggregate S-I correlation somewhat, from 0.54 to 0.42 , it is clear that most of the comovement between aggregate saving and investment cannot be attributed to the business cycle. The first column if the table shows that the private gap is anti-cyclical, while the public gap is pro-cyclical. But this appears not to be responsible for the very negative correlation between the gaps. After extracting the business cycle the correlation between the gaps remains practically unchanged at -0.67 . The other stylized facts are also not affected once the business cycle is extracted from the data.

The last column shows the cross country correlations. Both the cross country correlation between aggregate saving and investment rates (0.85) and between the gaps $(-0.83)$ are even much larger, in absolute size, than the corresponding time series moments. The aggregate S-I correlation is 0.43 higher than the private S-I correlation, which is similar to the time series moments. The negative correlation between the current account and investment in time series data is changed into a small positive correlation in cross country data.

Finally, for a set of 8 countries Table 4 reports both time series and cross country moments when we extend the sample back to $1960 .{ }^{7}$ These are based on unfiltered data

\footnotetext{
${ }^{7}$ The countries are Belgium, Canada, Finland, Germany, Netherlands, Sweden, UK, US.
} 
and the national accounts saving measure. The cross country moments are based on 1960 saving and investment rates. The stylized facts for the time series moments apply to the longer sample as well. Not surprisingly given the fact that the sample now covers a period with significant capital controls, the average time series correlation between aggregate S-I rates is even higher $(0.77)$, while the average correlation between the gaps is even lower $(-0.80)$. The correlation between private S-I rates is 0.22 , and therefore remains significantly lower than between aggregate S-I rates. Most cross country moments for the 1960 cross section are also qualitatively similar to the 1989 cross section. The only moment that does not appear to be robust to the sample is the country correlation between private and government saving. It becomes positive for the longer sample. Related to that, there is also a positive cross country correlation between the government gap and private saving. In 1989 countries with a large budget deficit have both high private saving and low private investment. In 1960 though a relatively large budget deficit is primarily financed through a crowding out of private investment.

\section{The Model}

Consider a world with $J$ countries, indexed by $i$. The population in country $i$ is $H_{i}$. The world population is $H=\sum_{i=1}^{J} H_{i}$. Variables below are denoted in per capita terms.

The same good is produced in each country and can be used either for consumption or investment purposes. The production technology in country $i$ is Cobb Douglas:

$$
Y_{i t}=e^{\theta_{i t}}\left(X_{t} N_{i t}\right)^{1-\alpha} K_{i t}^{\alpha}
$$

where $N_{i t}$ the fraction of time devoted to work and $K_{i t}$ is the capital stock in country $i$. $X$ measures labor augmenting deterministic technological progress which grows at the rate $g: X_{t+1}=(1+g) X_{t}$. $\theta_{i}$ is a country specific technology index, which follows an $\operatorname{AR}(1)$ process:

$$
\theta_{i t}=\rho_{\theta} \theta_{i t-1}+\epsilon_{i t}^{\theta}
$$

Here $\epsilon_{i t}^{\theta}$ is $N\left(0, \sigma_{\theta}\right.$ i.i.d. distributed, with a correlation of $\omega$ across countries.

In each country private agents have identical preferences defined over consumption, 
leisure and domestic government consumption:

$$
E \sum_{t=1}^{\infty} \beta^{t} \frac{\left(z_{i t} F\left(L_{i t}\right)\right)^{1-\gamma}}{1-\gamma}, \quad z_{i t}=\left(\lambda C_{i t}^{\frac{\rho-1}{\rho}}+(1-\lambda) G_{i t}^{\frac{\rho-1}{\rho}}\right)^{\frac{\rho}{\rho-1}}
$$

Since the total time endowment is normalized to $1, L_{i t}=1-N_{i t}$. (3) is the most general form of utility capturing the observation that per capita hours worked displays no trend, while income, consumption, investment and capital all grow at the same rate in the deterministic steady state ${ }^{8}$. The intertemporal elasticities of substitution of consumption and leisure are, respectively, $1 / \gamma$, and $\xi=1 /\left(\frac{L F_{L L}}{F_{L}}-\gamma \frac{L F_{L}}{F(L)}\right)>0$. The intratemporal elasticity of substitution between public and private consumption is $\rho$.

The CES specification for the total consumption index as a function of private and government consumption has not, to our knowledge, been explored before. In most simulated models where government consumption enters the utility function, it enters in a linear combination with private consumption. ${ }^{9}$ Kollman (1993) allows it to enter in a Cobb Douglas form. But since he only considers permanent government spending shocks, it does not play much of a role. ${ }^{10}$ Hansen and Wright (1992) suggest that the CES specification may be potentially interesting, but do not study its implications.

Concerning the asset market we assume that all agents can freely borrow and lend through an international bond market with a real interest rate $r_{t}$ from period $t$ to $t+1$. While we therefore allow for intertemporal asset trade, there is no risksharing across countries. We assume that agents own the property rights to firms in their own country. This assumption is in accordance with a great deal of evidence that international portfolio diversification is very limited. For example, at the end of 1989 US investors held $94 \%$ of their equity portfolio in US stock, while Japanese residents held 98\% in Japanese stock (see French and Poterba (1991)). ${ }^{11}$ Moreover, as is well known (e.g. Backus, Kehoe and Kydland (1992)) the assumption of perfect risksharing implies

\footnotetext{
${ }^{8}$ See King, Plosser and Rebelo (1987).

${ }^{9}$ See for example Otto (1992), Aschauer (1985), Kormendi (1983), Katasitis (1987), and Canova (1992).

${ }^{10}$ Kollman (1993) also allows government spending to enter utility through the subjective time discount rate. He finds that this can have a significant effect on private consumption, even when government spending shocks are permanent. In this paper we abstract from that possibility.

${ }^{11}$ Here we do not attempt to endogeneize the home bias. Pesenti and van Wincoop (1996) and Bottazzi,
} 
much larger consumption correlations across countries than observed in the data. And income correlations are generally negative. The assumption that instead there is only international trade in a riskfree bond has also been made in Baxter and Crucini (1995) and van Wincoop $(1995,1996)$.

At date $t$, after observing the production, government spending and tax rate shocks, agents choose how much to work, how much to consume and how much to invest. The representative agent of country $i$ maximizes expected utility (3), subject to a budget constraint, capital accumulation equation, and transversality condition:

$$
\begin{gathered}
B_{i t}=\left(1+r_{t-1}\right) B_{i t-1}+\left(1-\tau_{i t}\right) Y_{i t}-I_{i t}-C_{i t} \\
K_{i t+1}=(1-\delta) K_{i t}+\phi\left(\frac{I_{i t}}{K_{i t}}\right) K_{i t} \\
\lim _{t \rightarrow \infty} \beta^{t} E C_{t}^{-\gamma} B_{i t}=0
\end{gathered}
$$

In (4), $\tau_{i t}$ is the tax rate on domestic output and $B_{i t}$ denotes per capita bond holdings by country $i$ residents at the end of period $t$. The adjustment cost function $\phi($.$) in (5)$ is concave. ${ }^{12}$

First order necessary conditions from maximization are:

$$
\begin{aligned}
& z_{i t}^{-\gamma} F\left(1-N_{i t}\right)^{1-\gamma}\left(\frac{C_{i t}}{z_{i t}}\right)^{\frac{-1}{\rho}}=\beta\left(1+r_{t}\right) E_{t} z_{i t+1}^{-\gamma} F\left(1-N_{i t+1}\right)^{1-\gamma}\left(\frac{C_{i t+1}}{z_{i t+1}}\right)^{\frac{-1}{\rho}} \\
& z_{i t}\left(\frac{C_{i t}}{z_{i t}}\right)^{\frac{1}{\rho}} \frac{F_{L}\left(1-N_{i t}\right)}{F\left(1-N_{i t}\right)} / \lambda=\left(1-\tau_{i t}\right)(1-\alpha) Y_{i t} / N_{i t} \\
& E_{t}\left[\frac{\left(1+r_{t}\right)}{\phi_{i t}^{\prime}(.)}-\alpha\left(1-\tau_{i t+1}\right) \frac{Y_{i t+1}}{K_{i t+1}}\right]= \\
& E_{t} \frac{1}{\phi_{i t+1}^{\prime}(.)}\left[1-\delta+\phi_{i t+1}(.)-\phi_{i t+1}^{\prime}(.) \frac{I_{i t+1}}{K_{i t+1}}\right] \quad i=1, . ., N
\end{aligned}
$$

Eqn. (7) is an intertemporal consumption tradeoff condition. Eqn. (8) represents the intratemporal tradeoff condition between consumption and leisure. Eqn (9) is a tradeoff condition between consumption and investment.

Pesenti and van Wincoop (1996) consider the extent to which home bias is a result of optimal hedging strategies associated with, respectively, non-traded goods and non-traded claims on human capital.

${ }^{12}$ As is well known, e.g. from Mendoza (1991), Backus, Kehoe and Kydland (1992) and Baxter and Crucini (1993), it is necessary to introduce some type of friction in the model that inhibits capital mobility in order to prevent excessive volatility of investment. Mendoza (1991) and Baxter and Crucini (1993) introduce a cost of adjustment in capital, while Backus, Kehoe and Kydland (1992) introduce a small transportation cost, quadratic in next exports. 
The government's period budget constraint is:

$$
D_{i t}=\left(1+r_{t-1}\right) D_{i t-1}-T_{i t}+G_{i t}+I_{i t}^{g}
$$

where $T_{i t}=\tau_{i t} Y_{i t}$ is total tax revenue, $G_{i t}$ and $I_{i t}^{g}$ denote public spending on consumption and investment, and $D_{i t}$ is government debt at the end of period $t$. Although the government is not required to balance its budget each period, by making stochastic tax and spending processes depend on last period's debt $D_{i t-1}$ we can insure that the public debt to income ratio does not growth without bound as long as the coefficients on the public debt rate satisfy certain conditions (see Buiter (1984) and Cardia (1991)).

These government fiscal processes are assumed to follow

$$
\begin{gathered}
\tau_{i t}-\tau=\rho_{\tau}\left(\tau_{i t-1}-\tau\right)+\nu_{\tau} d_{i t-1}+\mu_{\tau} b s_{i t-1}+\epsilon_{i t}^{\tau} \\
\ln G_{i t}-\ln G_{i t-1}=\rho_{g}\left(\ln G_{i t-1}-\ln Y_{i t-1}-\ln (G / Y)\right)+\nu_{g} d_{i t-1}+\mu_{g} b s_{i t-1}+\epsilon_{i t}^{g} \\
\ln I_{i t}^{g}-\ln I_{i t-1}^{g}=\rho_{i}\left(\ln I_{i t-1}^{g}-\ln Y_{i t-1}-\ln \left(I^{g} / Y\right)\right)+\nu_{i} d_{i t-1}+\mu_{i} b s_{i t-1}+\epsilon_{i t}^{i}
\end{gathered}
$$

$d_{i t}=\frac{D_{i t}}{Y_{i t}}, b s_{i t}=\frac{B S_{i t}}{Y_{i t}}$ are the government debt to GDP ratio and budget surplus to GDP ratio, respectively. The parameters $\tau, \ln (G / Y)$ and $\ln \left(I^{g} / Y\right)$, without a time subscript, refer to steady state fiscal variables. The budget surplus at time $t$ is equal to the government saving minus investment gap: $T_{i t}-G_{i t}-r_{t-1} D_{i t-1}-I_{i t}^{g}=D_{i t}-D_{i t-1}$. So the policy rules depend both on the size of the debt and its rate of change.

The rules for government consumption and investment are not in rates. If we were to adopt the same type of policy rule as for the tax rate a $10 \%$ rise in output would automatically lead to a $10 \%$ rise in government spending, which makes government spending far too procyclical. Instead here government spending responds with a lag to a rise in output. As a result the budget surplus as a fraction of output becomes procyclical, which is confirmed in Table 1.

The innovations to the three fiscal processes, and the technology process, are all normally distributed. Within each country we allow for nonzero contemporaneous correlations between the government consumption, investment and tax rate shocks and between fiscal shocks of the same type across countries. Because they are different in nature, fiscal shocks are assumed to be independent from technology shocks. 
The model is closed by the world bond market equilibrium condition:

$$
\sum_{i=1}^{J} \frac{H_{i}}{H} B_{i t}=\sum_{i=1}^{J} \frac{H_{i}}{H} D_{i t}
$$

World bond holdings by the private sector must equal world debt issued by governments. The interest rate is determined endogenously by this bond market equilibrium condition.

Approximate loglinear decision rules for the control variables as functions of global and country specific state variables are obtained by following the method for solving multi-country models developed in van Wincoop (1995). A brief description of the method in the context of this paper is provided in Appendix B. In order to simulate the dynamic response to shocks, we will now need to choose values for the technology and preference parameters and estimate the parameters of the four stochastic processes.

\section{Estimation and Calibration}

\subsection{Estimation of Stochastic Processes}

Data used in the estimation of the stochastic processes comes are listed in Appendix A. A broad definition of net taxes is used to measure $T$, which equals total current receipts of the general government (primarily tax revenues), minus subsidies and other current transfers.

The three processes governing the behavior of the government fiscal variables are jointly estimated using Zellner's seemingly unrelated regression technique. This provides estimates that are more efficient than OLS estimates using single equations if their disturbance vectors are correlated. The three fiscal equations are written as :

$$
\mathrm{y}_{i}=X_{i} \beta_{i}+\epsilon_{i} \quad i=1,2,3
$$

Each of these three equations is first estimated with OLS, using a panel of data for all 15 countries and the time period 1975-1989.

The equations are subsequently stacked and written as $\mathrm{y}=X \beta+\epsilon$ :

$$
\left[\begin{array}{l}
\mathbf{y}_{1} \\
\mathbf{y}_{2} \\
\mathbf{y}_{3}
\end{array}\right]=\left[\begin{array}{lll}
X_{1} & & \\
& X_{2} & \\
& & X_{3}
\end{array}\right]\left[\begin{array}{l}
\beta_{1} \\
\beta_{2} \\
\beta_{3}
\end{array}\right]+\left[\begin{array}{l}
\epsilon_{1} \\
\epsilon_{2} \\
\epsilon_{3}
\end{array}\right]
$$


Zellner's SURE estimator is an estimated generalized least squares estimator :

$$
\hat{\beta}=\left[X^{\prime}\left(\hat{\Sigma}^{-1} \otimes I\right) X\right]^{1} X^{\prime}\left(\hat{\Sigma}^{-1} \otimes I\right) \mathbf{y}
$$

Here $\Sigma$ is the contemporaneous variance covariance matrix of $\epsilon$. The estimator $\hat{\Sigma}$ is constructed based on the OLS residuals $\hat{\epsilon}_{i}=\mathbf{y}_{i}-X_{i} \mathbf{b}_{i}$.

The results are reported in Table 5 both with and without including the budget surplus in the fiscal rules. The budget surplus always enters insignificantly and only has the expected sign for the tax rule. Therefore we will use the fiscal rules without the budget surplus in the benchmark simulation. The signs of the three coefficients on the public debt to GDP ratio are right, in the sense that the tax rate rises and the government spending falls when the debt rate rises. The coefficients are significant for both government spending rules. Moreover, numerical simulations show that they are of sufficient magnitude to insure that the government debt to income ratio does not explode in response to shocks, and therefore the government budget constraint is satisfied. ${ }^{13}$

The productivity indices are based on Solow residuals calculated as $\theta_{i t}=\ln Y_{i t}-(1-$ $\left.\alpha_{i}\right) \ln N_{i t}$, where $Y$ is real GDP and $N$ is hours worked (see data appendix). We estimate a stationary $A R(1)$ process with GLS for the productivity parameter, using the panel of country Solow residuals, after first subtracting out the country specific time average. ${ }^{14}$ The estimated coefficient for the AR(1) process is 0.949 with standard deviation 0.019 . This is a similar degree of persistence as in other studies, such as Backus, Kehoe and Kydland (1992). ${ }^{15}$ The standard deviation of the technology innovation is $\sigma_{\theta}=1.59 \%$, with a correlation of $\omega=0.15$ across countries.

\footnotetext{
${ }^{13}$ To rule out Ponzi schemes in steady state the debt cannot grow at a rate faster than the interest rate. This indeed holds when the debt to income rate does not explode in response to shocks (so that the steady state growth rate of $D$ is not higher than $g$ ) since $r>g$ is required for utility to be well defined.

${ }^{14}$ Since hours worked data are missing for three countries, the estimation of the Solow residual process is based on 12 countries.

${ }^{15}$ They also allow for technology spillovers across countries though. We do not allow for spillovers since Backus et al. find that this leads to very high cross country consumption correlations even in autarky (no asset trade). Baxter and Crucini (1995) also find this to be the case in the two country bond economy.
} 


\subsection{Parameterization of the Model}

There are two sets of underlying economic parameters to choose: (i) the preference parameters $\lambda, \gamma, \rho, \beta$ and $\xi$ and (ii) the technology parameters $\alpha, \delta, g$, and those describing the adjustment cost function $\phi($.$) .$

In the benchmark parameterization we set $\lambda=1$, so that government consumption does not enter the utility function. In the sensitivity analysis where we allow for government consumption in the utility function $\lambda$ is chosen so that the steady state marginal utilities from private and government consumption are identical when the ratio of private to government consumption matches the average found in the data at a relative price of one. We experiment with various values for the elasticity of substitution $\rho$ between private and government consumption.

In the benchmark parameterization $\gamma$ is set at 2, corresponding to a finding by Beaudry and van Wincoop (1996) for the United States. ${ }^{16}$ Sensitivity analysis is done as well. The growth rate $g$ is set at 0.0207 , the average consumption growth rate over the sample and all countries. The steady state Euler equation for consumption is $\beta=\frac{(1+g)^{\gamma}}{1+r}$, where $r$ is the steady state interest rate. This means that, given $g$ and $\gamma$, the steady state interest rate is determined by $\beta$. We set $\beta$ such that $r$ is 0.0291 , the average real interest rate over the sample and all countries. ${ }^{17}$ The survey in Pencavel (1986) shows that most estimates of the intertemporal elasticity of substitution of labor are quite low (less than 0.5 ). We set $\xi=0.4$ in the benchmark, which leads to a volatility of hours worked close to that in the data. We experiment with an even lower value in the sensitivity analysis.

For the technology parameters the rate of depreciation $\delta$ is set to $10 \%$ per annum, a standard assumption in RBC models. $(1-\alpha)=.54$ is the average labor share in the data. The other three 'production' parameters involve the adjustment cost function $\phi$. As in Baxter and Crucini (1993), we assume that $\phi$ is such that the deterministic steady

\footnotetext{
${ }^{16}$ That study uses a panel of state level consumption data. The study finds that estimates of the intertemporal elasticity of substitution of consumption based on aggregate (national) data are quite imprecise.

${ }^{17}$ The nominal interest rate is the T-bill rate reported in the IFS, or, if not available, the money market rate. We subtract the CPI inflation rate.
} 
state of the model is the same as that without adjustment costs. This implies that $\phi(\delta+g)=\delta+g$ and $\phi^{\prime}(\delta+g)=1$. The second order derivative of the adjustment cost function is captured by $\eta=-\left(\phi^{\prime} / \phi^{\prime \prime}\right) \div(I / K)$, which is the elasticity of the investmentcapital ratio with respect to Tobin's $q\left(1 / \phi^{\prime}\right)$. A higher $\eta$ leads to more volatility of private sector investment in the model. Since we don't know much about this parameter we set it such that the average standard deviation of the private investment rate matches that in the model. This is the case for $\eta=5$.

A couple more miscellaneous parameters need to be chosen. The first is the relative country size $H_{i} / H$, which is set based on 1980 GDP shares. The second is initial bond holdings. The net international investment position $B-D$ is non-stationary. Its level at time zero is therefore another parameter, which we set at zero for all countries. A country's government debt is stationary though. Its steady state level, as a ratio to output, is set at 0.46 for all countries. This is the average over the sample. Similarly, the average government consumption and investment rates are respectively 0.18 and 0.034. The steady state tax rate is then endogenous: $\tau=(r-g) d+\frac{G}{Y}+\frac{I^{g}}{Y}=0.218$.

\section{Results}

\subsection{The Benchmark Parameterization}

The results for the benchmark parameterization are shown in Table 6. The model moments are based on 100 simulations of a 15 year period. The standard deviations are shown in parentheses. Both model and data moments involving saving and investment rates are based on unfiltered data. The data moments are based on the benchmark saving measure. The first column under model moments shows the results with both technology and fiscal shocks. The next two columns show the contribution to these results by technology shocks alone, and fiscal shocks alone. For the fiscal shocks the results for only tax shocks and only spending shocks (government consumption and investment) are reported as well. The final column shows the results based on the "basic saving" measure, assuming both technology and fiscal shocks.

Under a combination of technology and fiscal shocks the model performs remarkably 
well under the benchmark parameterization. First, the average correlation between aggregate saving and investment rates is 0.55 , practically identical to that in the data. Second, the correlation between private saving and investment is significantly less than between aggregate saving and investment. For both definitions of saving the difference is 0.19 , quite close to the 0.24 in the data for the the definition of basic saving. ${ }^{18}$ Third, the average correlation between the private and government saving minus investment gaps is very negative $(-0.54)$, and only slightly more than one standard deviation from that in the data (-0.68). Related to that, the government gap has a positive correlation with private investment (the budget deficit crowds out private investment), and a negative correlation with private saving. These correlations are also of similar magnitude as the data. Fourth, there is a strong positive correlation between the current account and the private gap ( 0.70 , versus 0.63 in the data), while the correlation between the government gap and the current account is close to zero (0.10, versus 0.04 in the data). Finally, there is a negative correlation between the current account and investment of -0.51 (versus -0.47 in the data) and a positive correlation between the current account and saving of 0.31 (versus 0.36 in the data). The volatility of the current account is also practically identical to that in the data.

In order to understand why the model performs so well, it is helpful to dissect the results and consider the separate contributions of technology and fiscal shocks alone. The next four columns of the table are helpful in this respect. The interpretation of correlations for individual shocks is also fascilitated by considering the impulse response functions. Figures 3 and 4 show the impulse response functions for a one standard deviation shock to the Solow residual, the tax rate, government consumption and government investment. ${ }^{19}$

First consider a technology shock. The government saving rate first rises and then

\footnotetext{
${ }^{18}$ As was discussed in section 2, the larger difference of 0.47 for the benchmark definition of saving is due to a very negative correlation between interest on government debt and government investment. In order to capture this it is necessary to introduce nominal shocks in the model, leading to large variability in the ex-post real interest rate.

${ }^{19}$ The impulse response functions are for the first country in the sample (Australia), but they are practically identical for the other countries.
} 
drops because government consumption responds with a lag to the increase in output. The response of private saving is affected by several factors. On the one hand the shock is temporary, which would induce a rise in private saving. On the other hand, output rises even more in the first 15 years after the shock because of the increase in the capital stock (and hours worked). This by itself leads to a drop in private saving in the immediate response to the shock. The net effect is that private saving rises only slightly immediately following the shock, and then rises further over the next 15 years. Private investment on the other hand rises significantly right after the shock, and then drops rapidly. The result in the second column of Table 4 is that aggregate saving and investment have a high positive correlation of 0.61 , but the correlation between private saving and investment is significantly lower. Private saving and investment change in opposite directions soon after the shock.

The rise in government saving and the drop in private saving minus investment leads to a negative correlation of -0.55 between the gaps. The sharp private investment boom also leads to a negative correlation between the current account and investment, and a large positive correlation between the private gap and the current account, all features that are consistent with the data.

Next consider fiscal shocks. A tax shock leads to a rise in government saving and a drop in private saving since the shock is temporary. ${ }^{20}$ The drop in private saving is reinforced by the fact that output is relatively low in the short run as hours worked drops due to the lower after tax wage rate. Since as a result the drop in private saving is slightly larger than the rise in government saving, national saving drops a bit. Private investment drops because the after tax marginal product of capital is lower. The net result, as shown in the fourth column of Table 4, is that private saving and investment have a high positive correlation of 0.72 , higher than that between aggregate saving and investment (0.34). This is clearly inconsistent with the data. The large changes in government and private saving in opposite directions lead to a negative correlation of

\footnotetext{
${ }^{20}$ Ricardian equivalence plays an important role here. Ricardian equivalence does not exactly hold here though because (i) taxes are not lump sum and (ii) future government spending rises a bit in response to a rise in taxes today.
} 


\section{-0.83 between the gaps.}

Finally consider government spending shocks. Consider for example an increase in government consumption. This obviously leads to a drop in government saving. Private saving does not change much because the government spending shock is temporary and the future tax rate is not very sensitive to the debt rate. Private investment drops a bit because of the anticipated rise in future taxes. There is now a quite negative correlation of -0.50 between private saving and investment, but this is of little significance since both private saving and investment don't respond much to the shock. The private and government gaps move in opposite directions, contributing to their negative correlation. But this is also of limited significance because the private gap is not very volatile in response to spending shocks. It is nonetheless worth pointing out that all four shocks in the model lead to a significantly negative correlation between the private and government gaps.

Although most of the action clearly comes from technology and tax shocks, either of these shocks alone does not fully account for what is going on in the data. Technology shocks for example lead to a government gap that is much too procyclical. This is balanced out by a strongly anti-cyclical government gap with the tax shocks. Technology shocks also lead to correlations between the government gap and both private investment and saving that are far too high. These correlations are very negative for the tax shocks, again balancing the results. As a final example, the correlation between private and government saving is positive and large in response to technology shocks. This is balanced out by a much too negative correlation for tax shocks alone.

\subsection{Alternative filters and cross country moments}

Table 7 reports time series moments for alternative filters, as well as cross country moments. The moments are based on the benchmark parameterization with both technology and fiscal shocks. The results can be directly compared to the data moments in Table 3. As is the case in the data, the main features of the model still hold for alternative time series filters. The correlation between private saving and investment remains significantly lower than between aggregate saving and investment. The correlation be- 
tween the gaps is still very negative, now even more so for the first difference filter and the $\mathrm{HP}(100)$ filter. The private gap has a strong positive correlation with the current account. This is only weakened a bit for the $\mathrm{HP}(100)$ filter, but the standard error is large in that case. The government gap is almost uncorrelated with the current account in all cases. As in the data, the current account is even more negatively correlated with investment at the higher frequencies (first difference filter and $\mathrm{HP}(100)$ filter).

In two respects the model performs somewhat worse for the first difference and $\mathrm{HP}(100)$ filter. The correlation between total saving and investment is too high: respectively 0.83 and 0.82 versus 0.45 and 0.48 in the data. This is because of the strong comovement between total saving and investment in the immediate response to both technology and tax shocks. Second, the correlation between the current account and saving turns significantly negative. As can be seen from Figure 3, only in the immediate response to technology and tax shocks do saving and the current account change in opposite directions. After four years they have changed in the same direction, leading to the positive comovement for unfiltered data.

The last two columns of Table 5 report cross country moments based on 1989 saving and investment rates. Here the results are sensitive to the starting date of the model simulations. We start from a steady state in the first year of the simulations: all per capita variables are identical across countries. It is clear from the impulse response functions that the response to shocks are different at different horizons. Moreover, starting the simulations at an earlier date allows for larger cross country variability in the saving and investment rates as more shocks accumulate. The results are reported both for a starting date of the simulations in 1950 and 1975. ${ }^{21}$

Even though the model performs quite well for the time series moments, it cannot replicate the main stylized facts for cross country moments. In particular, the model cannot account for both the very large cross country correlation between aggregate saving and investment (0.85) and the very negative correlation between the gaps $(-0.83)$.

\footnotetext{
${ }^{21}$ The time series moments are based on the sample 1975-1989, with simulations starting in 1975. However these moments are not much affected if the simulations are started earlier, as long as the moments are still computed over the 1975-1989 sample (as in the data).
} 
When starting the simulations in 1975 these correlations are respectively 0.55 and -0.23 . When starting the simulations in 1950 these correlations are 0.15 and -0.58 .

The larger cross country correlation between aggregate saving and investment when simulations start in 1975 can be understood based on the impulse response functions in Figure 3. Saving and investment change in the same direction in the short run for both technology and tax shocks. But after 12 years for the technology shock and 5 years for the tax shock they have changed in opposite directions compared to the saving and investment rates before the shock. Similarly, the larger correlation between the gaps when simulations start in 1975 is most likely a result of the fact that at an intermediate horizon of 5 to 15 years the gaps move in the same direction in response to technology shocks.

The cross country correlation between the current account and saving, and between the current account and the private S-I gap, is much too high for both starting dates. The saving rate and the current account are both non-stationary in the model, while the investment rate is stationary. As shown in Figure 3, in the long run both saving and the current account change in response to shocks, and by an equal amount. Finally, the cross country variation of the current account is too high, especially when simulations start in 1950.

\subsection{Sensitivity Analysis}

Results from sensitivity analysis are reported in Tables 8 and 9 for time series moments. $\eta$ and $\xi$ are reduced in respectively the first and second experiments, in both cases leading to a sharp drop in investment volatility. The main results are not significantly affected though, with the exception of the correlation between the current account and investment, which is too high when $\eta$ is lowered to 3 . The next experiment raises the AR coefficient for the technology process to 0.999 , so that it effectively becomes a random walk. The model then performs far worse. Most importantly, the correlation between aggregate saving and investment turns negative. Output is expected to rise in the future in response to a positive technology shock as the capital stock expands and the higher productivity is maintained. As a result saving drops, while investment rises. A lower 
AR coefficient of 0.9 , considered in the last column of Table 8 , has very little effect on the results however.

In Table $9 \gamma$ is lowered from 2 to 1 , in which case consumption and leisure are additively separable in utility. Investment volatility is reduced and the correlation between the current account and investment is now too high. But the other main results still hold.

The third column adds the budget surplus to the fiscal rules. This has practically no effect on the results. This is not surprising since the estimated coefficients on the budget surplus are small (and insignificantly different from zero). We also considered adding the lagged current account to GDP ratio to the fiscal rules. Summers (1988), Tobin (1983) and Westphal (1983) have argued that the high correlation between total savings and investment might be a result of the fact that governments respond endogenously to current account imbalances. For the argument to hold one would therefore expect government taxation to depend negatively and government spending to depend positively on the current account. However, we find that the current account to income ratio enters insignificantly and with the wrong sign in both the taxation and government consumption rules. In the government investment equation it is significant (a t-value of 4.7), but with the wrong sign: a current account deterioration leads to a rise in government investment.

In the next column government consumption is added to the utility function. The elasticity of substitution between private consumption and government consumption, $\rho$, is set at 1.001. Maybe surprisingly, this has little effect on the results. We also experimented with different elasticities of substitution between private and public consumption. The only moment that is significantly affected is the correlation between private and public consumption itself (not reported in the tables). It drops as $\rho$ rises.

We have the following explanation for the rather insignificant role of government consumption in the utility function. Only the effect of anticipated changes in government consumption on the intertemporal marginal rate of substitution of consumption matters. But such anticipated changes are relatively small since $\rho_{g}$ is only 0.116 . Moreover, given the fact that the average observed ratio of $G / C$ in the data is only 0.31 , relatively little 
weight is attached to government consumption. For example, when we choose $\rho=1$, so that government consumption enters utility in a Cobb Douglas form with a weight of 0.24 , with $\gamma=2$ this implies that a $1 \%$ expected rise in government consumption relative to the steady state growth path, lowers the growth rate of private consumption by only $0.14 \%$.

The final column in Table 9 allows for separate tax rates $\tau_{i K}$ on capital income and $\tau_{i L}$ on labor income. The tax rate in first order condition (8), the tradeoff between consumption and leisure, is then $\tau_{i L}$. The tax rate in first order condition (9), the tradeoff between consumption and investment, is $\tau_{i K}$. It is assumed that $\tau_{i L}$ and $\tau_{i K}$ follow the same process as $\tau_{i}$ in eqn. (11). The only difference is that the innovations are now not perfectly correlated anymore. The innovation in the labor tax equation is $\epsilon_{i t}^{\tau L}=\epsilon_{i t}^{\tau}+v_{i t}$, and $\epsilon_{i t}^{\tau}=(1-\alpha) \epsilon_{i t}^{\tau L}+\alpha \epsilon_{i t}^{\tau K}$. The shock $v_{i t}$ is uncorrelated with all other shocks in the model. The larger the volatility of $v_{i t}$, the lower the correlation between the labor and capital tax rates. In Table 9 this correlation is assumed to be $0.5 .{ }^{22}$ The results are practically identical however to those in the benchmark parameterization. Even when the correlation is close to zero the results are still not significantly affected.

Overall we can conclude that most of the results are robust to parameterization. The only exception is a random walk in the Solow residual, which leads to a significant deterioration of model performance.

Table 10 shows the results from sensitivity analysis with respect of six of the cross country moments. It turns out that the conclusion that the model performs poorly in accounting for cross country moments is robust to parameterization. For none of the parameterizations do we simultaneously find a high cross country correlation between aggregate saving and investment and a very negative cross country correlation between the gaps. This is true both when the simulations start in 1950 and in 1975 . The cross country correlation between the current account and the private gap is too high for all parameterizations. And the cross country variation in the current account is too high

\footnotetext{
${ }^{22}$ For the US Gravelle (1994) computes a time series for the effective marginal tax rate of capital. She also reports the individual marginal tax rate. The residuals of an $A R(1)$ regression for both tax rates (based on the sample 1975-1989) have a correlation of 0.42 .
} 
when simulations start in 1950, with the exception of a random walk for the Solow residual.

\section{Summary and Conclusions}

After decomposing aggregate saving and investment into its public and private components we have documented a variety of "stylized facts" associated with saving and investment rates for a sample of 15 countries over the period 1975-1989. Some of the most striking and robust empirical regularities are the following. First, the correlation between private saving and investment rates is significantly lower than between aggregate saving and investment rates. Second, there is a very negative correlation between government and private S-I gaps. Third, the budget deficit is on average uncorrelated with the current account, while there is a large positive correlation between the private S-I gap and the current account. Finally, there is a strong negative relationship between investment and the current account and a positive relationship between saving and the current account.

In order to see whether these empirical relationships are consistent with a world of perfect capital mobility we developed a multi-country model with free trade in a riskfree bond and calibrated it to the fifteen OECD countries. The model performs remarkably well in accounting for the time series relationships, including the stylized facts listed above. Nonetheless the model is not able to capture the cross sectional aspect of the data. In particular, the model cannot account for both the large cross country correlation between aggregate saving and investment rates and the very negative cross country relationship between the gaps. As a result of non-stationarity of the saving rate and cointegrated national saving and current account, the cross country correlation between the saving rate and the current account is also much too high in the model.

Future work needs to focus more on the cross sectional aspect of the data. This has received little attention in analytical work so far because of the focus on small open economy and two country models. It is possible that the model performs better once we change the setup to induce stationarity of the saving rate, or, closely related to that, a 
stationary distribution of world wealth. This can be done by either endogeneizing the time discount rate, as in Mendoza (1991), or by considering a finite horizon model, as in Cardia (1991).

A second possible problem with the model is that there is no nominal uncertainty because there is only trade in a bond with a real return. In practice international trade in indexed bonds bonds is negligible. Allmost all trade is in nominal bonds, which leads to exchange rate and inflation uncertainty. At a theoretical level Bacchetta and van Wincoop (1995) show in the context of a two country general equilibrium model that nominal risk leads to a dampening of capital flows and closer relationship between saving and investment when there is only international trade in nominal bonds. Consistent with this, Bayoumi (1990) and Obstfeld (1995) find a lower cross country saving investment correlation during the gold standard than the recent floating rate period.

Another important direction for research is to compare the stylized facts for countries to those for regions within a country. Since regional capital markets are highly integrated, evidence on regions can provide an important benchmark against which to compare the country evidence. Work along this line has recently been undertaken for Japanese regions by Iwamoto and van Wincoop (1994). Sharp differences between regions and countries are found. In particular, the time series correlation between total saving and investment for Japanese prefectures is positive, but much smaller than for countries. The correlation between private saving and investment is similar to that for total saving and investment. And the average correlation between the private sector and local government S-I gaps is negative, but quite small. A possible explanation of the difference between regions and countries may again exchange rate risk. Regions within a country all use the same currency and therefore exchange rate risk does not affect interregional asset trade. Future work should aim at better understanding such differences between regions and countries, as it may shed light on the degree of financial integration of countries. 


\section{Appendix A: The Data and Definitions of Variables}

The fiscal policy variables and the aggregate, public and private saving and investment series are taken from the UN National Accounts and measure annual data from 1975-1989. The variables are all measured in nominal terms and divided by nominal GDP to report them in rates.

saving : Both the "benchmark" and "national accounts" measures of gross nominal saving are defined as nominal GNP less private consumption expenditure less government consumption expenditure. This isFor the "basic saving" measure it is instead defined as nominal GDP less private and government consumption expenditure.

government saving: The "national accounts" definition of net government saving is total current receipts minus government final consumption expenditure minus subsidies and other current transfers minus property income (which is largely interest payments on the government debt). In order to calculate gross government saving we add in general goverment consumption of fixed capital. Because in the data these interest payments are in nominal terms, they include an inflationary component. The "benchmark" saving measure corrects this by subtracting an inflation component from nominal interest on government debt. This entails adding to the national accounts definition a term equal to inflation times pubic debt. Inflation is calculated using the CPI from the International Financial Statstics. See below for the data source on public debt. Finally, the "basic saving" measure is equal to total net taxes (see definition below), minus government consumption.

private saving : measured as the difference between gross saving and gross government saving.

invest ment: Gross capital formation.

government investment: Gross fixed capital formation of general government + increase in general government stocks.

private investment : Investment less government investment.

government consumption : Government final consumption expenditure

tax rates : our measure of taxes is really a "net" measure. It is given by (total current receipts of general government, primarily tax revenues) - (subsidies) - (other 
current transfers). The tax revenue data includes social security contributions received by the government.

public debt rate : debt data for all countries except Iceland is taken from the OECD Economic Outlook and Economic Outlook Historical Statistics and measures Gross Public Debt of the General Government. Iceland's Debt is taken from the IMF Government Finance Statistics Yearbook and measures total Debt of the Consolidated Central Government.

world interest rate(used in calibration): measured as an unweighted average of real interest rates in 13 countries (Greece and Iceland are missing). Real rates are constructed by subtracting out expected inflation from country nominal rates. Interest rates are T-bill rates, or where not available, money market rates. Inflation is calculated using the CPI index. Data for both are taken from the International Financial Statstics.

labor supply : Data on hours worked are taken from the Yearbook of Labour Statistics and measured as total employment times hours per week in the manufacturing sector. Hours worked data is not available for Greece, Iceland and Netherlands.

private consumption share $(\lambda)$ : private nominal consumption expenditure divided by the sum of private + government nominal consumption expenditure. Data is from the UN National Account Statistics.

labor's share in production : For each country a labor share parameter (1 $\alpha_{i t}$ ) is constructed by dividing labor compensation by GDP. These are averaged over time periods to create one observation for each country, which are then used in the construction of the Solow rediduals. They are also averaged over both time and countries to create one long run steady state observation used for calibration of $\alpha$. These data are from the OECD National Accounts Statistics.

technology index : measured by the Solow residual. It is calcualted as $\theta_{i t}=$ $\ln Y_{i t}-\left(1-\alpha_{i}\right) \ln N_{i t}$, where $Y$ is real GDP and $N$ is hours worked. Real GDP is taken from the UN National Account Statistics. 


\section{Appendix B: Computation of the Equilibrium}

Here we will briefly outline the solution technique, which is an application of the general method for solving multi-country models developed in van Wincoop (1995). After substitution of the production function and the private budget constraint into the other equations $(2,5,7-14)$, the model is described by $9 J+1$ equations. The old set of variables are replaced by a new set. Variables growing in steady state are divided by $X_{t}$. A logarithmic transformation is applied to variables that are always positive, with the exception of the tax rate. The equations are then linearized around the steady state.

The solution is found in two steps. In step one the linearized equations are aggregated, defining global variables as $x_{t}^{T}=\sum_{i=1}^{J} \frac{H_{i}}{H} x_{i t}$. After solving out for the interest rate, and substituting the global bond market equilibrium into the other equations, 8 equations are left. Adding the trivial equation $D_{t}^{T}=D_{t}^{T}$, the system can be summarized as

$$
E_{t} v_{t+1}=M v_{t} \quad v_{t}=\left(I_{t}^{T}, N_{t}^{T}, D_{t}^{T}, D_{t-1}^{T}, \tau_{t}^{T}, G_{t}^{T}, I_{t}^{g T}, K_{t}^{T}, \theta_{t}^{T}\right)
$$

Applying the King, Plosser, Rebelo (1987) technique, we solve for the control variables $I_{t}^{T}, N_{t}^{T}$ as a function of the global state variables $D_{t}^{T}, D_{t-1}^{T}, \tau_{t}^{T}, G_{t}^{T}, I_{t}^{g T}, K_{t}^{T}, \theta_{t}^{T}$. After substituting the equations for the control variables into the expression for the interest rate, we obtain the global interest rate as a function of the global state variables. In the second step the interest rate is substituted into the 9 country specific equations. Add to this 6 accumulation equations for the global state variables, which are directly obtained from the global solution in step 1. Finally, adding the trivial equations $B_{i t}=B_{i t}$, $D_{i t}=D_{i t}$, and $D_{t}^{T}=D_{t}^{T}$, we obtain 18 equations, which are summarized as

$$
\begin{aligned}
& E_{t} z_{i t+1}=Q z_{i t} \\
& z_{i t}=\left(I_{i t}, N_{i t}, B_{i t}, D_{i t}, \tau_{i t}, G_{i t}, I_{i t}^{g}, k_{i t}, \theta_{i t}, D_{i, t-1}, B_{i, t-1}, \tau_{t}^{T}, G_{t}^{T}, I_{t}^{g T}, K_{t}^{T}, \theta_{t}^{T}, D_{t}^{T}, D_{t-1}^{T}\right)
\end{aligned}
$$

Again applying King, Plosser, Rebelo (1987), we obtain equations for the control variables $I_{i t}, N_{i t}, B_{i t}$ as linear functions of the global and country specific state of the world. Note that one of the eigenvalues of $Q$ is one. This is a result of the fact that the system has a unit root. Shocks have a permanent effect on the level of bonds (and consumption). In this respect the model is similar to Baxter and Crucini (1995), and van 
Wincoop $(1995,1996)$, who consider two country bond economies, but different from Mendoza (1991) and Cardia (1991), who obtain stationarity by assuming respectively an endogenous time discount rate and a finite horizon setup. As in King, Plosser and Rebelo (1987), only eigenvectors associated with explosive eigenvalues need to be identified. While a linear combination of the elements of $z_{i t}$ may be permanently affected by a shock, it may not be explosive in response to a shock. Otherwise the system is unstable, and the transversality condition will be violated. 


\section{REFERENCES}

Ahmed, S., 1986, Temporary and Permanent Government Spending Shocks in an Open Economy, Journal of Monetary Economics 17, 197-224.

Argimon, I. and J.M. Roldan, 1994, Saving, Investment and International Capital Mobility in the EC Countries, European Economic Review 38, 59-67.

Aschauer, D., 1985, Fiscal Policy and Aggregate Demand, American Economic Review $75,117-127$.

Backus, D.K., P.J. Kehoe and F.E. Kydland, 1992, International Real Business Cycles, Journal of Political Economy:745-775.

Baxter, M. and M. Crucini, 1993, Explaining Saving-Investment Correlations, American Economic Review 83, no. 3, 416-436.

Baxter, M. and M. Crucini, 1995, Business Cycles and the Asset Structure of Foreign Trade, International Economic Review 36, no. 4, 821-854.

Baxter, M., 1993, Financial Market Linkages and the International Transmission of Fiscal Policy, working paper, University of Rochester.

Bayoumi, T., 1990, Saving-Investment Correlations, IMF Staff Papers 37, no. 2.

Beaudry, P. and E. van Wincoop, 1996, The Intertemporal Elasticity of Substitution: An Exploration using a US Panel of State Data, Economica, forthcoming.

Borensztein, E.R., 1989, Fiscal Policy and Foreign Debt, Journal of International Economics $26,53-75$.

Bosworth, B.P., 1993, Saving and Investment in a Global Economy, The Brookings Institution, Washington, D.C.

Bottazzi, L., P. Pesenti and E. van Wincoop, 1996, Profits, Wages and International Portfolio Diversification, European Economic Review, forthcoming.

Buiter, W.H., 1984, Fiscal Policy in Open, Interdependent Economies, NBER Working 
Paper 1429.

Canova, F., 1992, Sources and Propagation of International Business Cycles: Common Shocks or Transmission?, working paper, European University Institute, Firenze.

Cardia, E., 1991, The Dynamics of a Small Open Economy in Response to Monetary, Fiscal, and Productivity Shocks, Journal of Monetary Economics 28, 411-434.

Feldstein, M. and C. Horioka, 1980, Domestic Saving and International Capital Flows, Economic Journal 90,314-329.

Feldstein, M. and Bacchetta, P., 1991, National Saving and International Investment, in: D. Bernheim and J. Shoven (eds.), National Saving and Economic Performance, University of Chicago Press, Chicago.

Feldstein, M., 1983, Domestic Saving and International Capital Movements in the Long and the Short Run, European Economic Review 21, 153-156.

Finn, M.G., 1990, On Saving and Investment in a Small Open Economy, Journal of International Economics 29, 1-21.

French, K.R. and J.M. Poterba, 1991, Investor Diversification and International Equity Markets, AER Papers and Proceedings 81, 222-226.

Gravelle, J.G., 1994, The Economic Effects of Taxing Capital Income MIT Press, Cambridge.

Goldstein, M. and M. Mussa, 1993, The Integration of World Capital Markets, IMF Working Paper 93/95.

Hansen, G.D., and R. Wright, 1992, The Labor Market in Real Business Cycle Theory, Quarterly Review Spring 1992, Federal Reserve Bank of Minneapolis, 2-12.

Iwamoto, Y. and E. van Wincoop, 1994, Public and Private Savings and Investment:Regions versus Countries, working paper, Boston University.

Katasitis, O., 1987, On the Substitutability between Private Consumption and Government Spending in Canada, Canadian Journal of Economics 20, 533- 543. 
King, R.G., C.I. Plosser and S.T. Rebelo, 1987, Production Growth and Business Cycles: Technical Appendix, University of Rochester.

Kollmann, R., 1993, Fiscal Policy, Technology Shocks and the US Trade Balance Deficit, working paper, Universite de Montreal.

Kormendi, R., 1983, Government Debt, Government Spending and Private Sector Behavior, American Economic Review 73, 994-1010.

Marrinan, J., 1992, The Effects of Government Spending on Savings and Investment in an Open Economy, working paper, Universitat Pompeu Fabra.

Mendoza, E.G., 1991, Real Business Cycles in a Small Open economy, American Economic Review 81, no. 4, 797-818.

Missale, A., 1991, Debt and Maturity: The Evidence, working paper no. 12, Innocenzo Gasparini Institute of Economic Research, Milan.

Murphy, R.G., 1984, Capital Mobility and the Relationship between Saving and Investment Rates in OECD Countries, Journal of International Money and Finance 3, 327-342.

Obstfeld, M., 1986, Capital Mobility in the World Economy: Theory and Measurement, Carnegie Rochester Conference Series on Public Policy 24, 55-104.

Obstfeld, M., 1995, International Capital Mobility in the 1990s, in: P. Kenen (ed.), Understanding Interdependence: The Macroeconomics of the Open Economy, Princeton University Press, Princeton.

Otto, G., 1992, Testing a Present-value Model of the Current Account: Evidence from US and Canadian Time Series, Journal of International Money and Finance 11, 414-430.

Penvacel, J., 1986, Labor Supply of Men: A Survey, in: Orley Ashenfelter and Richard Layard, eds., Handbook of Labor Economics (North Holland, Amsterdam).

Pesenti, P. and E. van Wincoop, 1996, International Portfolio Diversification and NonTraded Goods, working paper, Princeton University. 
Roubini, N., 1988, Current Account and Budget Deficits in an Intertemporal Model of Consumption and Taxation Smooting, NBER working paper no. 2773.

Roubini, N. and J. Sachs, 1989, Political and Economics Determinants of Budget Deficits in Industrial Economies, European Economic Review 33,903-938.

Sachs, J., 1981, The Current Account and Macroeconomic Adjustment in the 1970s, Brookings Papers on Economic Activity 1, 201-268.

Stockman, A. and L.E.O. Svensson, 1987, Capital Flows, Investment and Exchange Rates, Journal of Monetary Economics 13, 349-369.

Soderstrom, H.Y., 1987, Sectoral Saving and Investment Patterns in 16 OECD countries, 1965-1982, in: M.J. Boskin, J.S. Flemming and S. Gorini (eds.), Private Saving and Public Debt, Basil Blackwell, Oxford.

Summers, L., 1988, Tax Policy and International Competitiveness, in: J. Frenkel (ed.), International Aspects of Fiscal Policy, NBER (University of Chicago Press, Chicago).

Tesar, L.L., 1991, Savings, Investment and International Capital Flows ,Journal of International Economics 31, 55-78.

Tobin, J., 1983, Comment on "Domestic Saving and International Capital Movements in the Long and the Short Run" by M. Feldstein, European Economic Review 21, 153-156. Westphal, U., 1983, Comment on "Domestic Saving and International Capital Movements in the Long and the Short Run" by M. Feldstein, European Economic Review 21, 153-156.

van Wincoop, E., 1995, Open Economy Real Business Cycle Models: A Multi-Country Approach, in process, Boston University.

van Wincoop, E., 1996, A Multi-Country Real Business Cycle Model with Heterogeneous Agents, Scandinavian Journal of Economics, forthcoming. 